\title{
IDENTIFICATION OF Paracoccidioides brasiliensis IN ADRENAL GLANDS BIOPSIES OF TWO PATIENTS WITH PARACOCCIDIOIDOMYCOSIS AND ADRENAL INSUFFICIENCY
}

Carlos Andrés AGUDELO(1,2,3), Carolina MUÑoZ(1), Alex RAMíREZ(1), Jonhairo GUTIERREZ(2), Santiago VELEZ(1), Juan Camilo PEREZ(2), Alejandro VELEZ(1,2), Angela María TOBON(3,4) \& Angela RESTREPO(3)

\begin{abstract}
SUMMARY
The authors report two cases of adrenal insufficiency secondary to infiltration of the adrenal glands by Paracoccidioides brasiliensis. The first patient had been treated for a chronic multifocal form of paracoccidiodomycosis 11 years ago. The diagnosis of the mycosis was done simultaneous with that of the adrenal insufficiency in the second patient. In both patients the diagnosis was done by direct visualization of fungus in adrenal biopsies. They were treated with hormonal supplements and itraconazol by 12 and six months, without relapses during the follow-up period.
\end{abstract}

KEYWORDS: Paracoccidioidomycosis; Adrenal insufficiency; Cortisol.

\section{INTRODUCTION}

Paracoccidioidomycosis (PCM) is one of the most prevalent endemic mycoses in Latin America; it is produced by the dimorphic fungus Paracoccidioides brasiliensis. The disease affects mainly the lungs but also the mucous membranes and the skin ${ }^{9}$. Adrenal involvement is also relatively frequent but varies according to the report and the methods employed for its diagnosis; in most cases, such diagnosis is established by indirect means such as demonstrating adrenal hypofunction after ACTH challenge or by measurement of its various metabolites. Nonetheless, the presence of the causative agent in the glands parenchyma is of rare observation, unless autopsy cases are considered. Only one case has been reported with observation of $P$. brasiliensis in the adrenals of a PCM patient, once he had been treated with apparent satisfactory results ${ }^{7}$.

The present report describes two PCM patients with adrenal insufficiency in whom $P$. brasiliensis was observed in biopsies of these glands; one of these cases had a previous diagnosis of PCM but was improperly treated while in the other, the first manifestation of the mycosis corresponded to adrenal hypofunction.

\section{REPORT OF CASES}

Case 1: A 51 year-old male, agricultural laborer coming from a rural setting with a history of smoking (16 cigarette packages per year) and a previous eight years record of chronic multifocal paracoccidioidomycosis with lung and tongue lesions plus weight loss; he was treated with itraconazole $200 \mathrm{mg}$ /day for only two months. His last complement fixation was reactive at high titers $(1: 1024)$. At the present consultation, he was having asthenia, adynamia, hyporexia and weight loss of three months duration. He was brought to the emergency unit due to conscience alterations, hyperthermia, dyaphoresis and pallor. Physical examination revealed a blood pressure of 90/60, bradychardia (50 beaths/minute) and skin hyperpigmentation. His renal function was deteriorated (serum creatinine $2.2 \mathrm{mg} / \mathrm{dL}$ ) with hyperkalemia $(9.7 \mathrm{mEq} / \mathrm{dL})$ requiring hemodyalisis in one occasion. Adrenal hypofunction was demonstrated on the bases of cortisol levels below $5 \mu \mathrm{g} / \mathrm{dL}$ (normal values: $5-38.4$ ) and $\mathrm{ACTH}$ at $50 \mathrm{pg} / \mathrm{mL}$ (normal values $0-46$ ). A chest contrasted tomography (TC) showed diffuse bilateral infiltrates predominating in the lower fields plus peripheral septal lines. TC of the adrenals revealed a $11 \mathrm{~mm}$ nodule of the left adrenal gland. Therapy was initiated with IV hydrocortisone and oral fludrocortisone $0.1 \mathrm{mg}$ given every $12 \mathrm{~h}$; this treatment allowed stabilization of the patient's clinical conditions with improvement of the adrenal function. He was released from the hospital with fludrocortisone and prednisone therapies. Four months later, however, he was re-admitted with similar symptoms, namely, poor general conditions and hypotension (80/50); this time he had fever $\left(38.8{ }^{\circ} \mathrm{C}\right)$. Laboratory examinations showed hyponatremia $(121 \mathrm{mEq} / \mathrm{dL})$, deteriorated renal function (creatinine $3.5 \mathrm{mg} / \mathrm{dL}$ ) and hypercalcemia $(7.9 \mathrm{mEq} / \mathrm{dL})$. Other tests (hemogram, coagulation and liver function studies) were within normal limits. Chest X-rays showed micro-calcifications and reticular infiltrates of the upper lobes.

Hyperkalemia was treated medically but controls taken at $48 \mathrm{~h}$ showed no improvement. At this time, low basal cortisol levels $(1.4 \mu \mathrm{g} / \mathrm{dL})$ were once more recorded; as a result, intravenous steroids were administered with some response of the renal function tests, diminished creatinine values $(1.2 \mathrm{mg} / \mathrm{dL})$ and later on, improvement of potassium values.

(1) School of Medicine, Universidad Pontificia Bolivariana.

(2) Departments of Internal medicine Critical Care and Laboratory Service, Hospital Pablo Tobón Uribe.

(3) Medical and Experimental Mycology Unit, Corporación para Investigaciones Biológicas/CIB.

(4) Internal Medicine, Hospital La María, Medellín, Colombia.

Correspondence to: Carlos Andrés Agudelo, Corporación para Investigaciones Biológicas, Carrera 72A \# 78B-141, Medellín, Colombia. E-mail: carlosagudelo@yahoo.com 


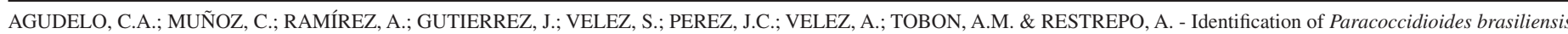
in adrenal glands biopsies of two patients with paracoccidioidomycosis and adrenal insufficiency. Rev. Inst. Med. trop. S. Paulo, 51(1): 45-48, 2009.

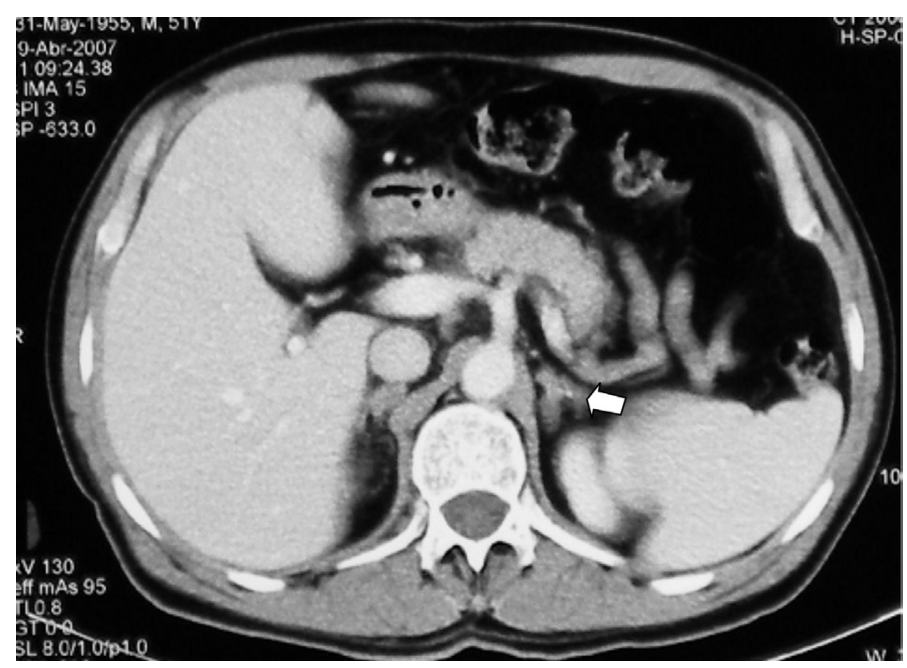

Fig. 1 - Nodules and calcifications observed in the adrenal gland of a patient with adrenal involvement due to Paracoccidioides brasiliensis.

A new abdominal TC revealed that the adrenal glands had a nodular aspect and presented calcifications but with no masses or hypercaptation of the contrast fluid (Fig. 1). Suspecting that the adrenal image could be due to $P$. brasiliensis, a right gland biopsy guided by TC was taken for histological and mycological studies. Results revealed infiltrating lesions with mononuclear cells, necrotic areas and presence of fungal structures compatible with the fungus.

The histopathologic results prompted itraconazol treatment at a $600 \mathrm{mg} /$ day dose for three days and then changing to $200 \mathrm{mg}$ /day for six months; this was done under ambulatory conditions. Additionally the patient received fludrocortisone $0.1 \mathrm{mg} /$ day, prednisone $2.5 \mathrm{mg}$ in the morning and $1.25 \mathrm{mg}$ in the evening. The patient was evaluated on an outpatient basis two months of starting treatment, when he was asymptomatic. Telephone follow-up was performed at 12 months, he continued with hormonal replacement, without crisis of adrenal insufficiency.

Case 2: A 45 year-old male from Medellín with a history of previous residence in Venezuela, consulted because of profuse diarrhea of one day duration. He had no previous pathological records except for excessive smoking. On admission he complained of emesis, asthenia, adynamia and loss of $6 \mathrm{~kg}$ weight in the last month. Clinical examination showed tachycardia (125 bpm), dehydration; low tensional values $(80 / 50 \mathrm{mmHg})$ plus persistently low media blood pressure, below $65 \mathrm{mmHg}$. No other abnormal findings were recorded. However, laboratory tests revealed hyperkalemia $(6.09 \mathrm{mEq} / \mathrm{dL})$, as well as acute renal insufficiency (creatinine $2.4 \mathrm{mg} / \mathrm{dL}$ ) and metabolic acidosis.

The patient was hospitalized in the ICU with the suspicion of septic shock originating in the gastrointestinal tract. He was treated with intravenous fluids and antibiotics, all of which failed. Inotropics at maximal doses were then administered. Basal cortisol levels were low $(1.63 \mu \mathrm{g} / \mathrm{dL})$ and quite below the normal values; there were also elevated ACTH values $(2500 \mathrm{pg} / \mathrm{mL})$. Systemic steroids were then administered resulting in normalization of blood pressure and improvement of the patient's clinical conditions; progressively, the renal failure resolved and the electrolytic abnormalities returned to normal.
HIV infection was discarded but adrenal gland involvement resulting from an infectious agent, such as Mycobacterium tuberculosis, was then suspected on the basis of chest bilateral fibrous scarring observed in the X-rays, together with residence in endemic areas. A TC of the abdomen was ordered and it revealed that the adrenal glands had a nodular aspect and were hyperplastic (Fig. 2). A biopsy of left gland was taken by laparoscopy; the histopathology results indicated the presence of extensive necrotic areas, multinucleated giant cells and yeast structures compatible with $P$. brasiliensis (Fig. 3). Serologic tests for paracoccidioidomycosis proved non-reactive.

The patient was given itraconazol (200 mg/day), prednisone (5 mg/ day) and fludrocortisone $(0.1 \mathrm{mg} /$ day $)$; he continued under treatment for 12 months with regular clinical check-ups, and during this time, no adrenal crisis were documented.

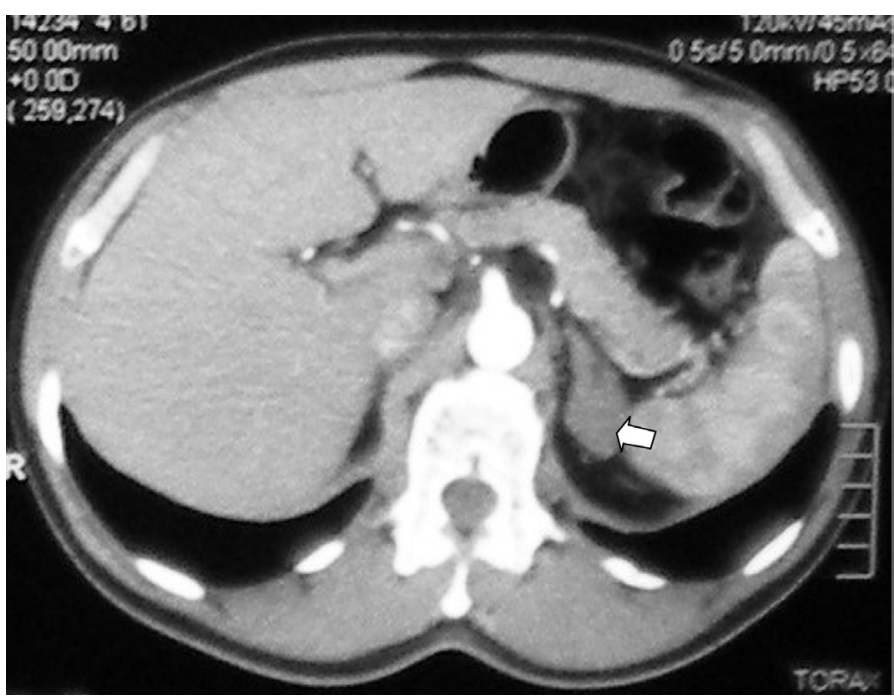

Fig. 2 - Nodular aspect of the adrenal glands in a patient with adrenal involvement by Paracoccidioides brasiliensis. Note marked hyperplasia.

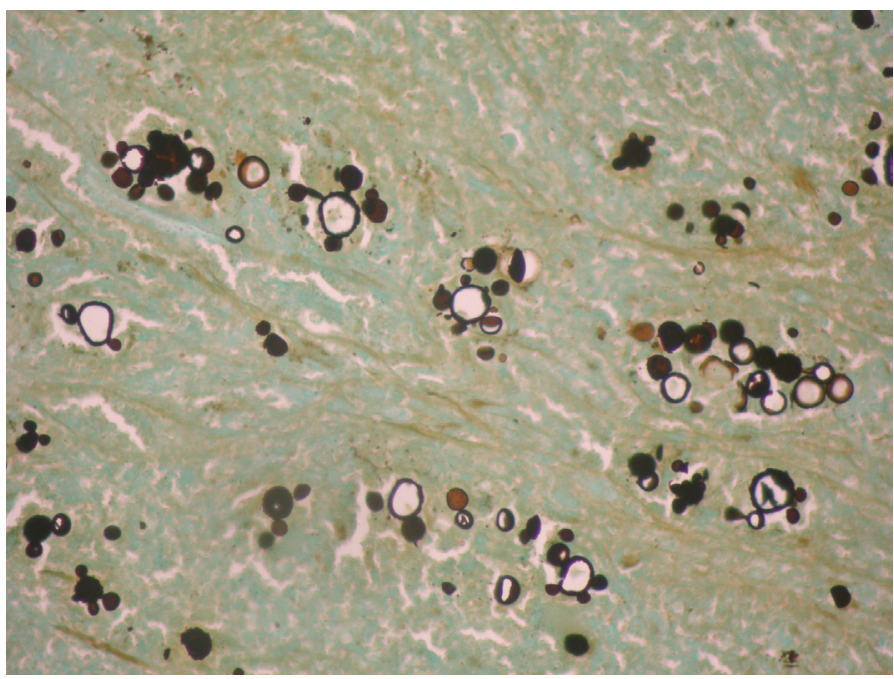

Fig. 3 - Paracoccidioides brasiliensis yeast cells in the adrenal gland of a patient with adrenal insufficiency. $100 \mathrm{x}$ 
AGUDELO, C.A.; MUÑOZ, C.; RAMÍREZ, A.; GUTIERREZ, J.; VELEZ, S.; PEREZ, J.C.; VELEZ, A.; TOBON, A.M. \& RESTREPO, A. - Identification of Paracoccidioides brasiliensis in adrenal glands biopsies of two patients with paracoccidioidomycosis and adrenal insufficiency. Rev. Inst. Med. trop. S. Paulo, 51(1): 45-48, 2009.

\section{DISCUSSION}

PCM is a systemic disease that involves mainly the lungs but disseminates to the mucous membranes, skin, lymph nodes and adrenals 9 . Due to the local immunosuppression existing in these glands attributable to their high steroid concentrations, they are more susceptible than other intra-abdominal organs to the hematogenous or lymphatic dissemination of certain microorganisms, fungi among them ${ }^{8}$.

The frequency of adrenal involvement in PCM varies among the different reports and depends on the criteria employed. In necropsy reports, adrenal gland invasion is as high as $85 \%-90 \%$ of the cases ${ }^{11,12}$. According to studies based on the measurement of cortisol metabolites in urine, as well as in those where cortisol quantification was done after ACTH stimulation, involvement varies from $44 \%$ to $48 \%{ }^{1,4}$. Such involvement has been minor when the cortisol delta was determined after ACTH administration (14\%) or when basal cortisol has been taken as a tool to diagnose adrenal failure ${ }^{1,2}$. Additionally, tomographic, ecographic and nuclear medicine images have revealed subclinical involvement of these glands ${ }^{5,14}$.

As a note of caution, certain antifungal treatments may also alter adrenal function ${ }^{1}$; in this regard, co-infection with tuberculosis is also important as it has been shown that during the infection itself cortisol levels may increase due to the stress to which the adrenals are subjected to ${ }^{2}$.

P. brasiliensis has seldom been observed in adrenal tissues; TORRES et al. observed for the first time the invasion of these glands by the fungus in two patients who died of disseminated $\mathrm{PCM}^{13}$. More recently, FAIÇAL et al. visualized the fungus in a needle aspiration biopsy of adrenal gland from a living patient who had adrenal insufficiency and had been diagnosed as PCM ten years previously?

In the present report, we analyze another two patients in whom $P$. brasiliensis was visualized in adrenal gland biopsies and who experienced adrenal deficiency. As reported for one of Faiçal's cases ${ }^{7}$, a patient in our series developed adrenal insufficiency after having received antifungal therapy suggesting fungal persistence in the glands, a site where $P$. brasiliensis would be protected from antifungal action. In this form, the adrenals could be regarded as a sanctuary that avoids fungal destruction allowing for further reactivation of the mycosis. In the remaining patient, the adrenal insufficiency was the only manifestation of the mycosis, a rare condition already reported by DEL NEGRO ${ }^{3}$. In both of our patients, the mycosis was severe and could have resulted in their death as there were renal function disturbances, hemodynamic instability and important electrolyte alterations. There were no pulmonary manifestations although in one case, there were residual lung lesions. These observations indicate that a certain control has been exerted by both the host and the antifungals on the primary organ lesions, leaving viable microorganisms in the adrenal glands.

In case 2, antibodies were not detected but this is not unusual. Approximately $10 \%$ of proven paracoccidioidomycosis patients do not present reactive tests; the real reason is not known but could be attributed to the sensitivity of the techniques used as none of them is capable of detecting $100 \%$ of the cases; additionally, low fungal burdens, or restricted infectious foci could also be incriminated $\mathrm{d}^{6,10}$.
It appears necessary to undertake prospective studies to evaluate the persistence of the fungus in the adrenal glands bringing forth the possibility of re-activation of the mycosis from this sanctuary.

\section{RESUMO}

Identificação do Paracoccidioides brasiliensis nas amostras de glândulas adrenais de dois doentes com paracoccidioidomicose e insuficiência adrenal

Os autores apresentam dois casos de insuficiência supra-renal secundária à infiltração das adrenais pelo Paracoccidioides brasiliensis. O primeiro paciente tinha sido tratado de paracoccidioidomicose crônica multifocal 11 anos atrás. No segundo paciente, o diagnóstico da micose foi feito de forma simultânea com o da insuficiência adrenal. Em ambos os pacientes, o diagnóstico foi feito pela visualização direta do fungo nas biopsias adrenais. Eles foram tratados com suplementos hormonais com itraconazol por seis a 12 meses, sem recaídas durante o período de acompanhamento.

\section{REFERENCES}

1. ABAD, A.; GÓMEZ, I.; VÉLEZ, P. \& RESTREPO, A. - Adrenal function in paracoccidioidomycosis: a prospective study in patients before and after ketoconazole therapy. Infection, 14: 22-26, 1986

2. COLOMBO, A.L.; FAIÇAL, S. \& KATER, C.E. - Systematic evaluation of adrenocortical function in patients with paracoccidioidomycosis. Mycopathologia (Den Haag), 127: 89-93, 1994.

3. DEL NEGRO, G. - Localização supra-renal da blastomicose sulamericana. São Paulo, 1961. (Tese de Livre-Docência - Faculdade de Medicina da Universidade de São Paulo)

4. DEL NEGRO, G.; WACHENBERG, B.L.; PEREIRA, V.G. et al. - Addison's disease associated with South American blastomycosis. Ann. intern. Med., 54: 187-197, 1961

5. DO VALLE, A.C.F.; GUIMARÃES, M.R.C.; CUBA, J.; WANKE, B. \& TENDRICH, M. - Recovery of adrenal function after treatment of paracoccidioidomycosis. Amer J. trop. Med. Hyg., 48: 626-629, 1993.

6. DO VALLE, A.C.F.; COSTA, R.L.B.; FIALHO-MONTEIRO, P.C. et al. - Interpretation and clinical correlation of serologic tests in paracoccidioidomycosis. Med. Mycol., 39: 373-377, 2001.

7. FAIÇAL, S.; BORRI, M.L.; HAUACHE, O.M. \& AJZEN, S. - Addison's disease caused by Paracoccidioides brasiliensis: diagnosis by needle aspiration biopsy of the adrenal gland. Amer. J. Roentgenol., 166: 461-462, 1996.

8. OÑATE, J.M.; TOBÓN, A.M. \& RESTREPO, A. - Insuficiencia suprarenal secundaria a paracoccidioidomicosis. Biomédica, 22: 280-286, 2002

9. RESTREPO, A. \&. TOBÓN, A.M. - Paracoccidioides brasiliensis. In: MANDELL, G.L.; BENNETT, J.E. \& DOLLIN, R. ed. Principles and practice of infectious diseases. 6. ed. Philadelphia, Elsevier, 2005. p. 3062-3068.

10. RESTREPO, A.; BENARD, G.; CASTRO, C.; AGUDElO, C.A. \& TOBON, A. Pulmonary paracoccidioidomycosis. Semin. resp. crit. Care Med., 29: 182-197, 2008

11. SALFELDER, K.; DOEHNERT, G. \& DOEHNERT, H.R. - Paracoccidioidomycosis Anatomic study with complete autopsies. Virchows Arch. Abt. A. Path. Anat., 348 51-76, 1969. 
AGUDELO, C.A.; MUÑOZ, C.; RAMÍREZ, A.; GUTIERREZ, J.; VELEZ, S.; PEREZ, J.C.; VELEZ, A.; TOBON, A.M. \& RESTREPO, A. - Identification of Paracoccidioides brasiliensis in adrenal glands biopsies of two patients with paracoccidioidomycosis and adrenal insufficiency. Rev. Inst. Med. trop. S. Paulo, 51(1): 45-48, 2009.

12. TENDRICH, M.; WANKE, B.;DEL NEGRO, G. \& WAJCHENBERG, B. - Adrenocortical involvement in paracoccidioidomycosis. In: FRANCO, M.; LACAZ, C.S.; RESTREPO, A. \& DEL NEGRO, G., ed. Paracoccidioidomycosis. Boca Raton, CRC, 1993. p. 303-310.

14. YAMAGA, L.Y.I.; BENARD, G.; HIRONAKA, F.H. et al. - The role of gallium-67 scan in defining the extent of disease in an endemic deep mycosis, paracoccidioidomycosis: a predominantly multifocal disease. Europ. J. nucl. Med. molec. Imaging, 30: 888894, 2003.

13. TORRES, C.M.; DUARTE, E.; GUIMARAES, J.P. \& MOREIRA, L.F. -Destructive lesion of the adrenal gland in South American blastomycosis (Lutz' disease). Amer. J. Path., 28: 145-155, 1952

Received: 7 July 2008

Accepted: 30 October 2008, 